\title{
Factors Influencing Bioassay of Porcine and Human Calcitonin
}

\author{
HirotoshI MORII*, HiROSHI IBAYASHI*, \\ EIICHIRO SHIMAZAWA** AND HIDEICHI ASANO** \\ *The Third Department of Internal Medicine, University of Tokyo, Tokyo and \\ **Department of Pharmacology, Research Laboratories, Teikoku Hormone \\ Mfg. Co., Ltd., Kawasaki, Kanagawa
}

\section{Synopsis}

Several factors which affect the sensitivity of calcitonin bioassay were investigated. As to the assay animals, Sprague-Dawley and Holtzman rats were more sensitive than Wistar rats. In mice, $\mathrm{C} 3 \mathrm{H}$ III strain gave better response to caicitonin than $\mathrm{CF} 1$ and ddN strains. In each strain, younger rats were more sensitive than older ones. It was also demonstrated that the longer was the period of low calcium diet, the more remarkable was the response of the Wistar rats to calcitonin. In Wistar rats, phosphate in drinking water improved the sensitivity of the assay and intravenous administration of calcitonin produced steeper dose-response curve than subcutaneous administration.

When 3 to 4-week-old Sprague-Dawley rats were utilized, the hypocalcemic acitivity was detected in 25 to $66 \mathrm{mg}$ of wet weight of human thyroid glands, while 5-week-old Sprague-Dawley rats were not so sensitive as to be able to detect hypocalcemic activity in $100 \mathrm{mg}$ of wet weight of human thyroid glands.

Two-week-old Holtzman rats were so sensitive that we detected hypocalcemic activity in $1 \mathrm{mg}$ of wet weight of a metastatic lymph node of the medullary thyroid carcinoma.

In attempts to increase the sensitivity of calcitonin bioassay, various modifications have been proposed. Difference in the sensitivty was shown among strains of rats (Cooper et al., 1967). Age (Care et al., 1967), duration of low calcium diet (Cooper et al., 1967), phosphate administration (Munson et al., 1967) and the route of calcitonin administration (Kumar et al., 1965) were found to be the factors that affect the sensitivity of the assay. In this report these factors were studied systematically with various strains of rats and mice.

Human thyroid glands have been found to contain less calcitonin than those of other species of animals. Therefore it is desirable to select better conditions in calcitonin bioassay of human thyroid glands.

Received for publication April 18, 1970.

\section{Materials and Methods}

\section{Animals}

Male rats of 3 strains (Holtzman, Sprague-Dawley and Wistar) 2 to 6 weeks of age and mice of both sexes of 3 strains ( $\mathrm{C} 3 \mathrm{H}$ III, CF 1 and $\mathrm{ddN}$ ) were used. Immediately after being the animals were placed on the low calcium diet prepared according to Kenny (1959), and on distilled water ad libitum for 1 to 4 days. When indicated, phosphate was given in drinking water as the $1 / 15 \mathrm{~N}$ phosphate solution, $\mathrm{pH}$ 7.4. Methods of both subcutaneous and intravenous administrations of calcitonin were compared. Intravenous administration was performed as one shot from the tail vein. The standard and test material was usually dissolved in $0.5 \mathrm{ml}$ of $0.01 \mathrm{~N} \mathrm{HCl}$.

\section{Preparation of Calcitonin}

\section{Standard calcitonin}

Standard calcitonin A was donated by Medical Research Council (MRC) in London. Commercially available porcine calcitonin (Wilson lot No. 135609) was standardized by the MRC standard.

2. Normal and pathologic human thyroids

Human thyroid glands were obtained during thyroidectomy or autopsy. In autopsy cases the specimens were 
obtained from the cadaver from non-endocrine diseases not later than $10 \mathrm{hr}$ after the death. Tissues were immediately frozen and minced in $1 / 10 \mathrm{~N} \mathrm{HCl}$. Homogenate was spun down $0^{\circ} \mathrm{C}$ at $600 \times \mathrm{g}$ for 30 $\mathrm{min}$ and again at $40,000 \times \mathrm{g}$ for $60 \mathrm{~min}$. The supernatant was assayed for the calcitonin activity.

\section{Medullary carcinoma}

A woman who had complained of an anterior neck tumor and occasional diarrhea was operated on her tumor at the age of 28 . The histological examination revealed a medullary carcinoma of the thyroid. Apparent metastasis to the satellite lymph nodes noted 1 year and 10 months later prompted the second operation. A lymph node weighing $493 \mathrm{mg}$ was obtained at the time of the second operation at the Second Department of Surgery, University of Tokyo. The tissue was minced and homogenized in $10 \mathrm{~m} l$ of $1 / 10 \mathrm{~N} \mathrm{HCl}$. The homogenate was centrifuged at $1000 \times \mathrm{g}$ for $30 \mathrm{~min}$ and the supernatant was again centrifuged at 35,000 $\times$ $\mathrm{g}$ for $30 \mathrm{~min}$. The supernatant was assayed for the calcitonin activity.

\section{Procedure of Experiment}

Rats were bled from the abdominal aorta $60 \mathrm{~min}$ after administration of the materials. Serum calcium was determined either by atomic absorption spectrophotometry or W. Webster's method (1962). Statistical analysis of bioassay was performed following the modified method of Bliss (1952).

\section{Results}

The calcitonin preparation (Wilson) standardized by the MRC (Medical Research Council) Standard A was utilized as a working

Table 1. Standardization of calcitonin

\begin{tabular}{ccccc}
\hline \hline & Standard A & & \multicolumn{2}{c}{$\begin{array}{c}\text { Calcitonin Preparation } \\
\text { (Wilson)* }\end{array}$} \\
\hline $\mathrm{mu}$ & Serum Ca mg/d $l$ & & $\mu \mathrm{g}$ & Serum Ca mg/d $l$ \\
\hline 20 & $8.8 \pm 0.21(5)$ & & 200 & $8.8 \pm 0.12(5)$ \\
40 & $7.7 \pm 0.14(5)$ & & 400 & $8.3 \pm 0.12(5)$ \\
80 & $7.7 \pm 0.14(5)$ & & 800 & $7.9 \pm 0.18(5)$ \\
\hline
\end{tabular}

Vehicle $9.8 \pm 0.07(10)$

i) Numbers in parentheses are numbers of animals.

ii) Assay animals were 5-week-old Holtzman male rats.

iii) All values are mean \pm SEM of serum calcium expressed as $\mathrm{mg} / \mathrm{d} l$.

iv) Mean calcitonin content of the preparation was $76.8 \mathrm{~m} \mu / \mathrm{mg}$ with the range of one standard error 76.5 to $77.1 \mathrm{~m} \mu / \mathrm{mg}$.

Low calcium diet was given for 1 day.

Calcitonin was injected subcutaneously.

* Lot No. was 135609.

Table 2. Effects of strains and age on the hypocalcemic response of animals to calcitonin

a) Rats

\begin{tabular}{|c|c|c|c|c|}
\hline Strain & $\begin{array}{c}\text { Age } \\
\text { in weeks }\end{array}$ & $\begin{array}{l}\text { Body weight } \\
\text { in grams }\end{array}$ & $\begin{array}{l}\text { Optimum dose } \\
\text { in MRC mu }\end{array}$ & $\lambda$ \\
\hline Wistar & 6 & $100 \sim 120$ & $30 \sim 120$ & $0.46 \pm 0.37(24)$ \\
\hline Sprague-Dawley & $\begin{array}{c}3 \sim 4 \\
5\end{array}$ & $\begin{array}{l}30 \sim 40 \\
80 \sim 100\end{array}$ & $\begin{aligned} 5 & \sim 20 \\
20 & \sim 80\end{aligned}$ & $\begin{array}{l}0.20 \pm 0.04(6) \\
0.27 \pm 0.17(18)\end{array}$ \\
\hline Holtzman & $\begin{array}{l}2 \\
5 \\
\end{array}$ & $\begin{aligned} 25 & \sim 30 \\
120 & \sim 140\end{aligned}$ & $\begin{aligned} 5 & \sim 10 \\
20 & \sim 80\end{aligned}$ & $\begin{array}{ll}0.06 & (1) \\
0.27 \pm 0.07 & (13)\end{array}$ \\
\hline \multicolumn{5}{|l|}{ b) Mice } \\
\hline Strain & & $\mathrm{C} 3 \mathrm{H}$ III & CF 1 & $\mathrm{ddN}$ \\
\hline Age in weeks & & 11 & 7 & 6 \\
\hline Body weight (g) & & 25 & 25 & 20 \\
\hline $\begin{array}{r}\text { Serum Ca } \\
\mathrm{mg} / \mathrm{d} l\end{array}$ & $\begin{array}{c}20 \mathrm{MRC} \mathrm{mu} \\
\text { Vehicle }\end{array}$ & $\begin{array}{r}9.8 \pm 0.16^{*}(5) \\
10.7 \pm 0.17^{*}(3)\end{array}$ & $\begin{array}{l}11.2 \pm 0.20(6) \\
11.1 \pm 0.23(6)\end{array}$ & $\begin{array}{l}12.2 \pm 0.29 \\
12.4 \pm 0.95\end{array}$ \\
\hline
\end{tabular}

a) Low calcium diet was given for 1 day in Sprague-Dawley and Holtzman rats and for 4 days in Wistar rats, except for 2-week-old Holtzman rats which were fasted $24 \mathrm{hr}$ instead of administration of low calcium diet.

Numbers in parentheses are numbers of experiments.

b) Animals were fasted overnight. Calcitonin was injected subcutaneously.

Numbers in parentheses are numbers of animals.

Difference was significant. $\quad * \mathrm{P}<0.025$

** $\mathrm{P}<0.005$ 
Table 3. Effect of duration of low calcium diet on the response to calcitonin in 6-weekold Wistar rats.

a) Response to $80 \mathrm{MRC}$ mu of calcitonin

\begin{tabular}{|c|c|c|c|c|}
\hline & \multicolumn{4}{|c|}{ Days of administration of low calcium diet } \\
\hline & 1 & 2 & 3 & 4 \\
\hline $80 \mathrm{MRC}$ mu & $9.6 \pm 0.19 *$ & $9.7 \pm 0.23 *$ & $9.6 \pm 0.16^{* *}$ & $9.7 \pm 0.35 * * *$ \\
\hline Vehicle & $10.3 \pm 0.11 *$ & $10.5 \pm 0.17 *$ & $10.8 \pm 0.17 * *$ & $11.3 \pm 0.11 * * *$ \\
\hline \multicolumn{5}{|c|}{ b) Response to $120 \mathrm{MRC}$ mu of calcitonin } \\
\hline & \multicolumn{4}{|c|}{ Days of administration of low calcium diet } \\
\hline & 1 & \multicolumn{2}{|c|}{4} & 4 \\
\hline $120 \mathrm{MRC} \mathrm{mu}$ & $9.5 \pm 0.17 * *$ & \multicolumn{2}{|c|}{$8.8 \pm 0.26 * *$} & $8.5 \pm 0.09 * *$ \\
\hline Vehicle & $10.9 \pm 0.15 * *$ & \multicolumn{2}{|c|}{$10.5 \pm 0.20 * *$} & $10.7 \pm 0.12 * *$ \\
\hline
\end{tabular}

Differences between vehicle and $80 \mathrm{MRC}$ mu administrations were significant.

$$
\begin{array}{r}
* \mathrm{P}<0.025 \\
* * \mathrm{P}<0.001 \\
* * * \quad \mathrm{P}<0.005
\end{array}
$$

All values are mean $\pm \mathrm{SEM}$ of serum calcium expressed as $\mathrm{mg} / \mathrm{d} l$. Calcitonin was injected subcutaneously.

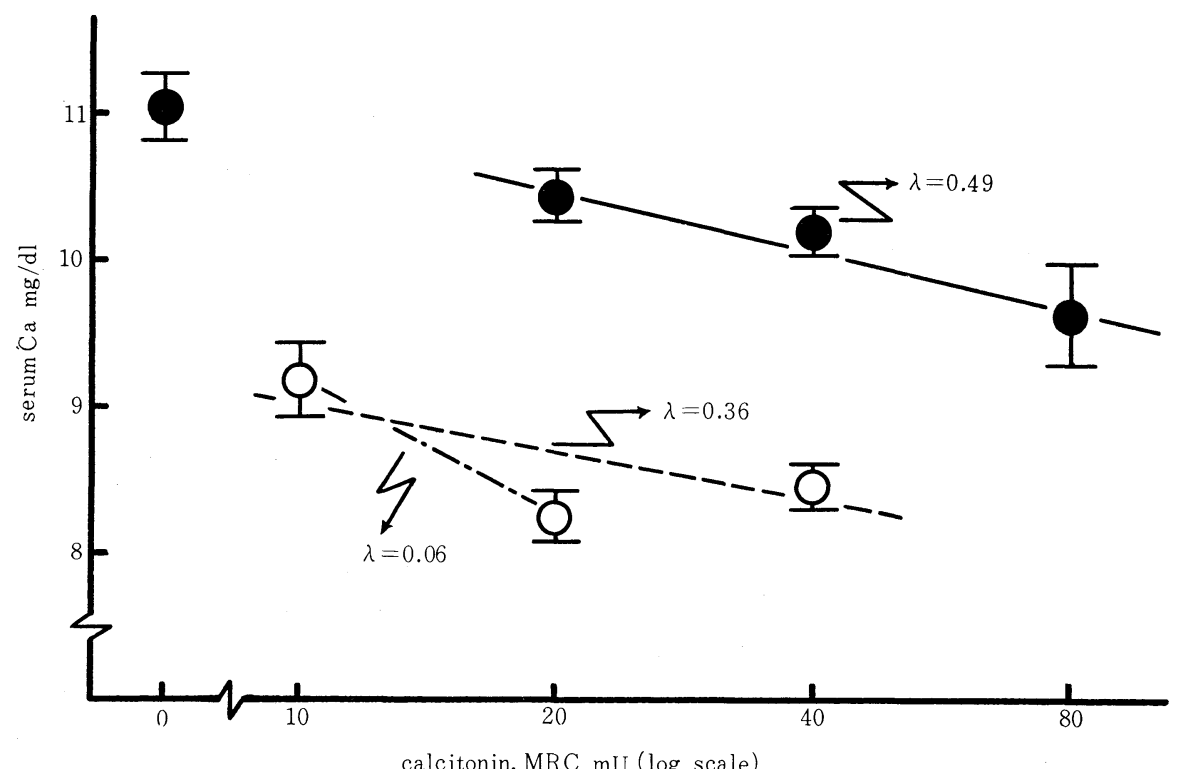

Fig. 1. Comparison of effects of subcutaneous and intravenous administration of calcitonin in 6-week-old Wistar rats.

Intravenous administration of calcitonin gave a smaller value of precision index than subcutaneous administration. $\lambda$ value for subcutaneous administration was 0.49 while that for intravenous administration was 0.36 . The first 2 points in the latter gave $\lambda$ value 0.06 . Low calcium diet was given for 4 days before bioassay.

호 mean $\pm \operatorname{SEM}(\mathrm{n}=5)$, - - s.c., --- $\bigcirc---$ i.v. 
standard in the subsequent experiments. The mean potency of this lot turned out to be 76.8 MRC mu/mg with the range of one standard error from 76.5 to $77.1 \mathrm{MRC} \mathrm{mu} / \mathrm{mg}$ (Table 1). The sensitivity to calcitonin was quite variable in the Wistar rats. The results were more consistent with those in Sprague-Dawley and Holtzman rats. In Sprague-Dawley and Holtzman strains the sensitivity was much higher in younger animals as compared with older animals (Table 2 a).

Among the 3 mice strains, the $\mathrm{C} 3 \mathrm{H}$ III mice responded well to calcitonin, but the CF 1 and ddN mice did not show the hypocalcemic response to calcitonin. The strain ddN showed hypercalcemia, but the animals did not respond to calcitonin.

As to the effect of duration of the low calcium diet, the hypocalcemic response was more pronounced in Wistar rats given the diet for a longer period in both cases of administrations of $80 \mathrm{MRC}$ mu and $120 \mathrm{MRC}$ mu of calcitonin
(Table $3 \mathrm{a}$ and $\mathrm{b}$ ).

The effect of routes of calcitonin administration was tested with the Wistar rats. Intravenous administration of calcitonin caused more marked hypocalcemic effect than that of subcutaneous injection of calcitonin (Fig. 1).

Animals given the $1 / 15 \mathrm{M}$ phosphate solution for the drinking water for 7 days showed steeper response to calcitonin (Fig. 2). When animals were administered $80 \mathrm{MRC} \mathrm{mu}$ of calcitonin, the mean serum calcium was 10.2 $\pm 0.14 \mathrm{mg} / \mathrm{d} l$ in control rats and $9.1 \pm 0.24$ $\mathrm{mg} / \mathrm{d} l$ in animals given the phosphate solution.

Calcitonin contents in human thyroids, both intact and pathologic, were assayed utilizing Sprague-Dawley and Holtzman rats. The 5week-old Sprague-Dawley rats weighing 70 $90 \mathrm{~g}$ were not sensitive enough for us to detet hypocalcemic activity of the extract from 100 $\mathrm{mg}$ of the thyroid. Only 2 out of 13 samples produced a statistically significant hypocalcemic response (Table 4 a). One out of 3

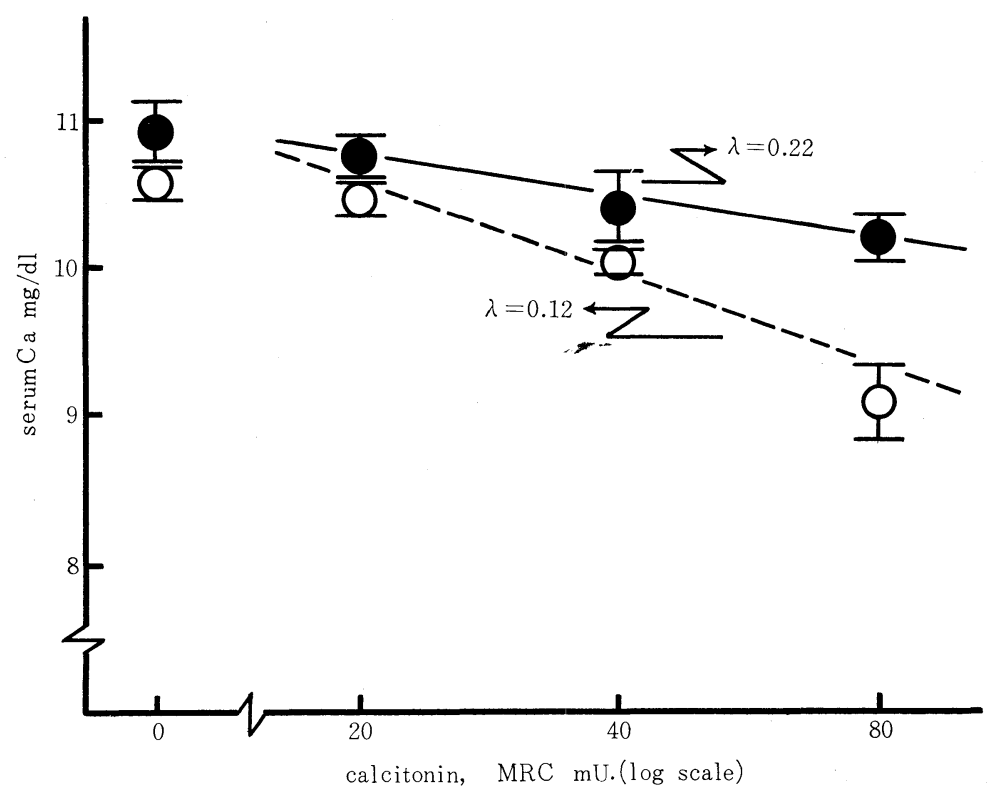

Fig. 2. Effect of phosphate on the response of animals to calcitonin in 6-week-old Wistar rats. When animals were given phosphate solution as drinking water, the response to calcitonin steeper $(\lambda=0.12)$ than control experiment $(\lambda=0.22)$. 호 mean $\pm \operatorname{SEM}(n=5)$, - control, ---- $\bigcirc----$ phosphate soln. Notice the animal strain.

Low calcium diet was given for 4 days.

Calcitonin was injected subcutaneously. 
samples showed statistically significant hypocalcemic activity when 5-week-old Holtzman rats were utilized (Table $4 \mathrm{~b}$ ). However, with 3 to 4-week-old Sprague-Dawley rats it was possible to detect the hypocalcemic activity in 25 to $66 \mathrm{mg}$ wet weight of the intact human thyroids. Calcitonin content in normal human thyroids ranged from 103 to $222 \mathrm{mu} / \mathrm{g}$ of wet weight (Table 5). A metastatic lymph node of medullary carcinoma contained 9422 MRC $\mathrm{mu} / \mathrm{g}$ (Table 6).

Table 4. Bioassay of human thyroid tissues utilizing 5-week-old Sprague-Dawley and Holtzman rats

a) Sprague-Dawley rats

\begin{tabular}{|c|c|c|c|c|c|c|c|c|c|}
\hline Initial & Age & Sex & $\begin{array}{l}\text { Pathologic } \\
\text { Diagnosis }\end{array}$ & $\begin{array}{l}\text { erum } \mathrm{Ca}(\mathrm{mg} / \mathrm{d} l) \\
\text { in rats given } \\
\text { extract of } \\
00 \text { mg of human } \\
\text { thyroids (A) }\end{array}$ & Serum Ca (B) & $\begin{array}{l}20 \mathrm{MRC} \mathrm{mu} \\
\text { of standard } \\
\text { calcitonin }\end{array}$ & $\lambda \stackrel{c}{c}$ & $\begin{array}{l}\text { Signifi- } \\
\text { cance of C } \\
\text { difference } \\
\text { between } \\
\text { A and B }\end{array}$ & $\begin{array}{l}\text { Calciton in } \\
\text { content } \\
\mathrm{mu} / \mathrm{g}\end{array}$ \\
\hline MA & 36 & 오 & $\begin{array}{l}\text { Papillary } \\
\text { Cystoadenoma }\end{array}$ & $10.1 \pm 0.14(3)$ & $10.0 \pm 0.06(5)$ & $9.7 \pm 0.15(5)$ & 0.23 & NS & \\
\hline TT & 49 & 우 & $\begin{array}{l}\text { Follicular } \\
\text { Adenoma }\end{array}$ & $9.9 \pm 0.06(3)$ & " & " & " & NS & \\
\hline FK & 27 & 우 & Colloid Adenoma & $10.1 \pm 0.32(3)$ & " & " & " & NS & \\
\hline NN & 42 & 우 & $\begin{array}{l}\text { Trabecular } \\
\text { Adenoma }\end{array}$ & $9.9 \pm 0.07(3)$ & " & " & " & NS & \\
\hline KK & 54 & 오 & Follicular Adenoma & $9.7 \pm 0.12$ & " & " & " & $\mathrm{P}<0.05$ & 171 \\
\hline SN & 38 & 우 & Tubular Adenoma & $9.8 \pm 0.22(3)$ & " & " & " & NS & \\
\hline $\mathrm{MK}^{*}$ & 45 & 우 & Intact & $10.1 \pm 0.09(3)$ & " & " & $"$ & NS & \\
\hline $\mathrm{YM}^{* *}$ & 20 & 오 & $\begin{array}{l}\text { Metastatic } \\
\text { Papillary } \\
\text { Adenocarcinoma }\end{array}$ & $9.8 \pm 0.04(3)$ & " & " & " & NS & \\
\hline $\mathrm{YM}^{* *}$ & 20 & 오 & $\begin{array}{l}\text { Papillary } \\
\text { Adenocarcinoma }\end{array}$ & $10.2 \pm 0.27$ & $10.4 \pm 0.11(5)$ & $9.5 \pm 0.08(5)$ & 0.22 & NS & \\
\hline $\mathrm{SM}^{* * *}$ & 33 & 오 & Intact & $10.1 \pm 0.13(4)$ & " & " & " & NS & \\
\hline $\mathrm{KI} \dagger$ & 17 & 우 & Intact & $9.6 \pm 0.26(3)$ & " & " & " & $\mathrm{P}<0.025$ & $5 \quad 188$ \\
\hline $\mathrm{YK} \dagger \dagger$ & 49 & $\hat{o}$ & Intact & $10.6 \pm 0.18(3)$ & $10.6 \pm 0.14(5)$ & $9.7 \pm 0.14(5)$ & 0.34 & NS & \\
\hline AI & 35 & 우 & $\begin{array}{l}\text { Papillary } \\
\text { Adenocarcinoma }\end{array}$ & $10.6 \pm 0.10(3)$ & " & " & " & NS & \\
\hline \multicolumn{10}{|c|}{ b) Holtzman rats } \\
\hline FO & 17 & 우 & $\begin{array}{l}\text { Parenchymatous } \\
\text { Adenomatous } \\
\text { Struma }\end{array}$ & $10.1 \pm 0.23$ & $10.6 \pm 0.19$ & $9.3 \pm 0.47(4)$ & 0.25 & NS & \\
\hline YA & 49 & 우 & Chr. Thyroiditis & $9.9 \pm 0.24(3)$ & " & " & " & $\mathbf{P}<0.05$ & 95 \\
\hline TK & 31 & 우 & $\begin{array}{l}\text { Papillary } \\
\text { Adenocarcinoma }\end{array}$ & $10.3 \pm 0.29$ & " & " & " & NS & \\
\hline
\end{tabular}

* The patient MK had follicular adenoma of thyroid in other parts.

** This mark indicates the same patient.

*** The patient SM died due to uremia.

$\dagger$ The patient KI died due to renal rickets and uremia.

$\dagger \dagger$ The patient YK died due to lung cancer.

All values were expressed as mean \pm SEM.

Low calcium diet was given for 1 day.

Calcitonin and samples were injected subcutaneously.

$\lambda$ is precision of bioassay. 
Table 5. Bioassay of human thyroid tissues utilizing 3 to 4-week-old Sprague-Dawley rats

\begin{tabular}{|c|c|c|c|c|c|c|c|c|c|}
\hline \multirow[b]{2}{*}{ Initial } & \multirow[b]{2}{*}{ Age } & \multirow[b]{2}{*}{ Sex } & \multicolumn{2}{|c|}{ Sample } & \multirow{2}{*}{$\begin{array}{c}\text { Vehicle } \\
\begin{array}{c}\text { Serum Ca } \\
\mathrm{mg} / \mathrm{d} l(\mathrm{~B})\end{array}\end{array}$} & \multirow{2}{*}{$\frac{\begin{array}{c}\text { Standard } \\
10 \mathrm{MRC} \mathrm{mu}\end{array}}{\underset{\substack{\text { Serum } \mathrm{Ca} \\
\mathrm{mg} / \mathrm{d} l}}{ }}$} & \multirow[b]{2}{*}{$\lambda$} & \multirow{2}{*}{$\begin{array}{c}\text { Significance } \\
\text { of } \\
\text { difference } \\
\text { between } \\
\text { A and B }\end{array}$} & \multirow{2}{*}{$\begin{array}{c}\text { Calcitonin } \\
\text { content } \\
\text { MRC } \\
\text { mu/g wet } \\
\text { weight }\end{array}$} \\
\hline & & & $\begin{array}{l}\text { Amount } \\
\text { administ- } \\
\text { ered (mg) }\end{array}$ & $\begin{array}{l}\text { Serum } \mathrm{Ca} \\
\mathrm{mg} / \mathrm{d} l(\mathrm{~A})\end{array}$ & & & & & \\
\hline TN & 31 & $\hat{0}$ & 66 & $8.6 \pm 0.08$ (3) & $9.25 \pm 0.16(4)$ & $8.3 \pm 0.34$ & 0.30 & $\mathrm{P}<0.005$ & 103 \\
\hline SM & 69 & $\hat{0}$ & 25 & $8.5 \pm 0.14$ (3) & $9.1 \pm 0.08$ & $7.7 \pm 0.32$ & 0.14 & $\mathrm{P}<0.05$ & 223 \\
\hline SF & 73 & $\hat{0}$ & 38 & $8.8 \pm 0.07$ & "I & "1 & & $\mathrm{P}<0.05$ & 124 \\
\hline MY & 21 & 今 & 20 & $8.8 \pm 0.14$ & $9.2 \pm 0.12(3)$ & $8.2 \pm 0.08$ (3) & 0.19 & NS & \\
\hline FK & 11 & 우 & 20 & $9.3 \pm 0.08$ & "I & " & & NS & \\
\hline
\end{tabular}

Numbers in parentheses are numbers of animals utilized. Causes of death are angina pectoris for T.N., myocard infarction for S.M., cor pulmonale for S.F., malignant thymoma for M.Y. and acute bronchitis for F.K.

All values were expressed as mean \pm SEM.

Low calcium diet was given for 1 day.

Calcitonin preparation and samples were injected subcutaneously. $\lambda$ shows precision of bioassay.

Table 6. Bioassay of extract of a metastatic lymph node from the medullary carcinoma

\begin{tabular}{|c|c|c|c|}
\hline \multicolumn{2}{|c|}{ Standard } & \multicolumn{2}{|c|}{$\begin{array}{l}\text { Extract of medullary } \\
\text { carcinoma }\end{array}$} \\
\hline Dose & $\begin{array}{c}\text { Serum } \mathrm{Ca} \\
\mathrm{mg} / \mathrm{d} l\end{array}$ & Wet weight & $\underset{\mathrm{mg} / \mathrm{d} l}{\operatorname{Serum}} \mathrm{Ca}$ \\
\hline \multirow{3}{*}{$5 \mathrm{mu}$} & 8.2 & \multirow{3}{*}{$1 \mathrm{mg}$} & 6.8 \\
\hline & 8.4 & & 7.8 \\
\hline & 8.3 & & 7.7 \\
\hline & mean 8.3 & & mean 7.4 \\
\hline \multirow{3}{*}{$10 \mathrm{mu}$} & 7.6 & \multirow{3}{*}{$2 \mathrm{mg}$} & 6.3 \\
\hline & 7.1 & & 6.6 \\
\hline & 7.4 & & 6.6 \\
\hline & mean 7.4 & & mean 6.5 \\
\hline
\end{tabular}

1. Calcitonin content was $9422 \mathrm{mu} / \mathrm{g}$ wet weight with 9351 to $9453 \mathrm{mu} / \mathrm{g}$ of one standard error.

2. Parallelism was proved between standard preparation and that of medullary carcinoma.

3. Bioassay was performed utilizing Holtzman rats of 2 weeks of age.

Assay animals were fasted for $24 \mathrm{hr}$ instead of administration of low calcium diet.

\section{Discussion}

It has already been established that the younger animals are more sensitive to calcitonin than the older. When the thyroids of sheep and goats of different ages were perfused with hypercalcemic blood, the extent of the resulting hypocalcemic response was smaller in older animals (Care et al., 1967). Strutridge
(1968) found that the equivalent hypocalcemia was produced in 3-week-old rats by doses less than one-third of those required in 5-week-old ones. Our results also indicated that the younger animals of both Holtzman and Sprague-Dawley strains produced the larger response in the lower dose range of calcitonin. Young Wistar animals (2 to 4-weekold) showed similar results, but not consistently. On some occasions the animals did not respond even to the large doses of the calcitonin.

Difference in sensitivity among the strains was also reported (Cooper et al., 1967). Among the 3 strains of rats, the Holtzman and Sprague-Dawley rats were much more sensitive than the Wistar. Mice of $\mathrm{C} 3 \mathrm{H}$ III strain was more sensitive to calcitonin than $\mathrm{CF} 1$ and $\mathrm{ddN}$ strains, although the latter 2 groups were younger than the $\mathrm{C} 3 \mathrm{H}$ III mice. A peculiar finding was the hypercalcemia in CF 1 and ddN strains, but the exact nature of this phenomenon is currently not clear. The sensitivity to human calcitonin was found to be better in mice of white Swiss strain than in rats (Lalijee et al., 1967).

Duration of low calcium diet was reported to alter the responsiveness of animals to calcitonin. Cooper et al. (1967) proposed that animals were more sensitive when fed with low calcium diet for 1 day than when fed for 4 
days. However, the reverse results were obtained in our experiments. The longer the period of the low calcium diet, the more sensitive was the animals to calcitonin. Such difference may be due either to the defference in strain or to the contents of phosphate in the low calcium diet. Phosphate (Munson, 1967) has been shown to increase the sensitivity of animals to calcitonin. Cooper et al. (1967) also pointed out that the difference in phosphate content in the diet could be a cause of the difference in the response to calcitonin when the calcium content was low in the diet. Pyrophosphate was also proposed to influence the sensitivity of the bioassay (Orimo, 1969).

The route of administration of calcitonin was found to be another factor to modify the response. Intravenous administration caused much greater response in rats than subcutaneous administration (Kumar et al., 1965). On the other hand, there was no difference in response between intravenous and intraperitoneal administration in mice (Laljee et al., 1967).

Calcitonin content in normal human thyroids varied from 103 to $223 \mathrm{mu} / \mathrm{g}$ wet weight in our experiment. Our results showed that 5week-old Sprague-Dawley rars were not practically suitable for the bioassay of human thyroids.

The maximum limit of time allowed in coilecting thyroid tissues from the cadaver was reported to be $12 \mathrm{hr}$ after death (Laljee et al., 1967). While our specimens were collected not later than $10 \mathrm{hr}$ after death and, moreover, mainly during autumn and winter seasons, most of the tissues showed definite amounts of calcitonin.

Parallelism in the dose response curves was established between the extract of a metastatic lymph node of the medullary carcinoma and standard preparation (Table 6). Although the content of calcitonin was very high in the metastatic lymph node of our case compared with that of normal thyroid tissue, the higher values have been reported. Tashjian et al. (1968) reported that the specific biologic activities of 2 cases of medullary carcinoma were 143 and $182 \mathrm{MRC} \mathrm{mu} / \mathrm{g}$ of fresh weight and MacIntyre (1969) showed that the medullary carcinoma was 5,000 times richer in calcitonin content than normal thyroids. The metastatic lymph node in our study contained only 60 times more calcitonin than normal human thyroids. It may be because the tissue happened to be the metastatic lymph node which was rich in the fibrous structure.

\section{Acknowledgment}

We should greatly appreciate Prof. Dr. Kiku Nakao, Third Department of Internal Medicine, University of Tokyo, for his direction of the investigation and review of the manuscript. We thank Drs. Haruhiro Ando and Ryuta Suzuki, Teikoku Hormone Mfg. Co., Ltd. for their understandings while this experimentation has been performed. We are very much indebted to Dr. Kunihiko Ito, Ito Hospital, Dr. Saburo Yoshimura at Medical Examiner's Office, Tokyo Metropolitan Government, and Dr. Yoshihide Fujimoto, Second Department of Surgery, University of Tokyo, for their kindness in permitting the investigation of human thyroid glands. Drs.Tatsuji Nomura and Kozaburo Ezaki at Central Institute for Experimental Animals were kind enough to let us utilize several strains of mice. Dr. Takuo Fujita kindly reviewed the manuscript. We are grateful for the generous supply of Standard A from Medical Research Council in London. Miss Ineko Morita's valuable assistance during the experiment is appreciated.

\section{References}

Bliss, C. I. The Statistics of Bioassay, Acad. Press, New York, (1952).

Care, A. D. and T. Duncan (1967). J. Endocrinol. 37, 107.

Cooper, C. W., P. F. Hirsch, S. U. Toverud and P. L. Munson (1967). Endocrinolgy 81, 610.

Kenny, A. D. and P. L. Munson (1959). Ibid. 64, 513.

Kumar, M. A., E. Slack, A. Edwards, H. A. Soliman, A. Baghdiantz, G. V. Foster and I. MacIntyre (1965). J. Endocrinol. 33, 469. Laljee, H. C. K., R. N. Smith and K. J. Dorrington (1967). Ibid. 39, 507. 
MacIntyre, I. (1969). "Calcitonin 1969" abstract.

Sturtridge, W. C. and M. A. Kumar (1968). J. Endocrinol. 42, 501.

Munson, P. L. and P. F. Hirsch (1967). Am. J. Med. 43, 678.

Tashjian, A. H. Jr. and K. E. W. Melvin (1968). New Engl. J. Med. 279, 279.

Orimo, H., T. Fujita and M. Yoshikawa (1969). "Calcitonin 1969" abstract.

Webster, W. (1962). Am. J. Clin. Pathol. 37, 330. 